\title{
Analysis of a scrambled gene: the gene encoding $\alpha$-telomere-binding protein in Oxytricha nova
}

\author{
Jennifer L. Mitcham, Aenoch J. Lynn, and David M. Prescott \\ University of Colorado, Department of Molecular, Cellular, and Developmental Biology, Boulder, Colorado 80309-0347 USA
}

Following cell mating in ciliates, a copy of the micronuclear genome is processed into a new macronucleus through massive cutting, reordering, splicing, elimination, and amplification of the DNA. DNA processing includes the deletion of short interrupting elements called internal eliminated sequences (IESs), followed by the splicing of the remaining segments, known as macronuclear destined sequences (MDSs). The MDSs in some micronuclear genes, such as actin I, are scrambled and must be reordered during IES removal and MDS splicing to yield a functional gene. Here, we describe the cloning, sequencing, and characterization of a different scrambling pattern for the gene that encodes the $\alpha$ subunit of the telomere-binding protein of Oxytricha nova. The micronuclear gene is made up of 14 MDSs in the scrambled order 1-3-5-7-9-11-24-6-8-10-12-13-14. Only the scrambled version is present in the micronucleus, and only the unscrambled version is present in the macronucleus. We propose that unscrambling occurs by homologous recombination guided by pairs of direct repeats at MDS-IES junctions. The patterned array of scrambling may be a clue to the origin of scrambling in this gene.

[Key Words: Oxytricha nova; DNA processing; macronuclear destined sequences; internal eliminated sequences; homologous recombination]

Received December 23, 1991; revised version accepted February 27, 1992.

Rearrangements of DNA sequences occur as a normal part of the life cycle of some eukaryotic organisms, although such changes are not common. In some cases, DNA sequence rearrangements may occur by gene conversion, others may involve RNA as an intermediate, but few seem to be accomplished by cutting and rearranging DNA segments themselves. Well-understood examples of the latter are the cutting and splicing of DNA during macronuclear development in Tetrahymena (Yao et al. $1990)$ and in differentiating mammalian immunocytes (Iwashima et al. 1988). DNA rearrangement is necessary to generate functional immunoglobulin and T-cell receptor genes. Similarly, rearrangement of DNA sequences is required to generate functional macronuclear genes from scrambled micronuclear precursors in hypotrichous ciliates. The hypotrichs represent an extreme in cutting, splicing, reordering, and elimination of DNA sequences as normal and necessary developmental events. Essentially every gene is processed, and all nonessential, nongenic DNA, representing $95 \%$ of the total sequence complexity, is eliminated (Lauth et al. 1976). Therefore, the hypotrichs offer an unusual opportunity to study ways in which an organism might manipulate its own DNA.

Hypotrichous ciliates such as Oxytricha nova contain two kinds of nuclei (micronuclei and macronuclei) in a single cell. The micronucleus contains high-molecularweight DNA, divides mitotically, and undergoes meiosis during cell mating. The macronucleus contains only low-molecular-weight, gene-sized DNA molecules (Prescott et al. 1971), divides amitotically, and has no apparent role in cell mating. During macronuclear development the micronuclear genome is amplified, extensively cut, reordered, spliced, reduced in complexity by DNA elimination and, finally, amplified again to produce a macronucleus containing, on average, $\sim 1000$ copies of $\sim 24,000$ different gene-sized molecules (Lauth et al. 1976). All of the $\sim 40$ macronuclear DNA molecules characterized so far contain a single transcription unit. The micronucleus is transcriptionally quiescent during cell proliferation, whereas the macronucleus is responsible for all transcription needed for cell growth and reproduction.

Macronuclear development occurs after cell mating. During mating, two cells fuse and form a cytoplasmic opening between them. The micronucleus in each cell undergoes meiosis, and the two cells exchange haploid micronuclei. An exchanged haploid micronucleus fuses with a stationary haploid micronucleus, and the result ing diploid micronucleus divides by mitosis without cell division. One of the mitotic products remains as a micronucleus, and the other develops into a new macronucleus during several days. The old macronuclei and unused haploid micronuclei degenerate while the new macronucleus develops. 
Macronuclear development begins with polytenization of the micronuclear chromosomes to 32-64 copies per chromosome (Ammermann 1965). The polytene chromosome organization is subsequently destroyed, gene-sized molecules are excised from the DNA, and telomere sequences are added to the ends of all molecules (Boswell et al. 1982; Roth and Prescott 1985). During these events, the genes are cut and spliced to remove internal eliminated sequences (IESs) that interrupt both coding and noncoding regions of micronuclear genes (Klobutcher et al. 1984). The presence of IESs divides a micronuclear gene into segments called macronucleardestined sequences (MDSs). When the IESs are removed, the MDSs are spliced to form a functional macronuclear gene. About $10^{5}$ IESs are removed from the $\sim 24,000$ genes. In the final stage of macronuclear development the gene-sized molecules are amplified an additional 16fold.

IESs were first discovered in an O. nova gene of unknown coding function named C2 (Klobutcher et al. 1984). In the micronuclear C2 gene, three IESs separate four MDSs. The MDSs in the micronuclear gene are arranged in the same order in which they occur in the macronuclear gene. Another O. nova gene, the micronuclear actin I gene, contains nine MDSs separated by eight IESs (Greslin et al. 1989). In contrast to the C2 gene, the MDSs in the micronuclear actin I gene are in a scrambled order and must be reordered during macronuclear development to produce a gene capable of encoding the actin I protein.

In this paper we describe a different pattern of MDS scrambling in the gene that encodes the $56-\mathrm{kD} \alpha$ subunit of the O. nova telomere-binding protein $(\alpha-\mathrm{TBP})$. Analysis of the $\alpha$-TBP gene is a step toward understanding the phenomena of IES removal, MDS reordering, and MDS splicing in $O$. nova.

\section{Results}

Cloning and sequencing of the micronuclear $\alpha$-TBP gene

A micronuclear DNA fragment containing the $\alpha$-TBP gene was selected from a $\lambda$ library of $O$. nova micronuclear DNA using a DraI fragment of the macronuclear $\alpha$-TBP gene cloned and sequenced previously by Gray et al. (1991). Sequence analysis of the $\alpha$-TBP micronuclear clone showed that the micronuclear gene is 2610 nucleotides long in contrast to the 2217-nucleotide macronuclear gene. Comparison of the sequence of the micronuclear gene (Fig. 1; DDB)/EMBL GenBank accession no. X59724) with the macronuclear gene (Gray et al. 1991) revealed that the micronuclear $\alpha$-TBP gene is composed of 14 MDSs separated by 13 IESs. Numbers $1-14$ were assigned to the MDSs according to the unscrambled order in which they occur in the functional, macronuclear version of the gene. The 14 MDSs in the cloned micronuclear gene occur in the scrambled order 1-3-5-7-9-112-4-6-8-10-12-13-14 (Fig. 2).

The scrambled micronuclear gene that we cloned does not correspond precisely in sequence with either of the two versions of the macronuclear gene for $\alpha$-TBP that have been cloned and sequenced previously (Gray et al. 1991). These versions are called S and A because they encode a serine and an alanine residue at position 312 , respectively. The micronuclear version cloned by us (called mic $\alpha \mathrm{K}$, or the $\mathrm{K}$ version) differs from the macronuclear $S$ version at 52 nucleotide positions and from the A version at 47 positions. Most of the nucleotide differences occur in the noncoding leader and trailer regions of the gene or in wobble configurations. The $\mathrm{K}$ version differs from the A version at only 1 of 496 amino acid residues-at residue 21 , where the $K$ version encodes a serine and the $A$ version encodes an alanine. The $K$ version differs from the $\mathrm{S}$ version at 3-amino-acid residues: at residues 21,312 , and 457 .

In addition to the amino acid differences, a transition in the $\mathrm{K}$ version at nucleotide 2001 (Fig. 1) creates a HindIII site in MDS 13; no HindIII sites are present in the $S$ or A versions. Repeated verification through sequence and Southern analyses of this restriction site polymorphism and of the other nucleotide differences makes it clear that the mic $\alpha \mathrm{K}$ clone does not contain the micronuclear precursor gene for the A or $\mathrm{S}$ versions of the $\alpha$-TBP gene.

\section{A HindIII-containing version of the $\alpha$-TBP gene is present in the macronucleus}

It is possible that micronuclear precursors for the $\mathrm{S}$ and A versions do not exist. This could be the case if the nucleotide differences that distinguish the $\mathrm{S}$ and $\mathrm{A}$ versions from the $\mathrm{K}$ version were introduced through DNA polymerase errors during years of vegetative growth without successful cell mating. Because mic $\alpha \mathrm{K}$ does not correspond with either the S or A macronuclear gene, it is also possible that the micronuclear $\mathrm{K}$ gene is not processed into a macronuclear gene.

To address these questions we tested for the presence of $\alpha$-TBP genes with and without a HindIII site in native macronuclear DNA from an exconjugant clone derived only 3 weeks after cell mating. Following cell mating, the old macronucleus is destroyed and a new macronucleus is developed. Examination of macronuclear DNA from the recent exconjugant clone ensures that we detect gene sequences represented in the micronucleus, because development of a new macronucleus always follows conjugation and because 3 weeks is far too short a time to expect mutational creation of new $S$ and $A$ versions of the $\alpha$-TBP gene. We do not have opposite mating-type strains of $O$. nova and therefore cannot control mating behavior. However, intraclonal mating (selfing) occurs frequently. Selfers do not complete macronuclear development at room temperature, but an occasional exconjugant survives when the mating (selfing) and macronuclear development are carried out at $12^{\circ} \mathrm{C}$. To ensure isolation of a true exconjugant, mating pairs, joined by a cytoplasmic bridge, were removed to individual culture dishes at $12^{\circ} \mathrm{C}$ and observed closely for successful completion of macronuclear development. 
Mitcham et al.

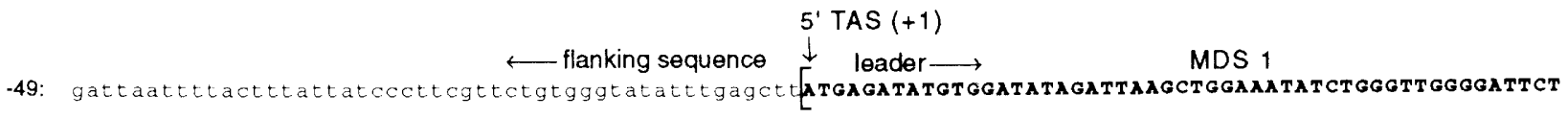

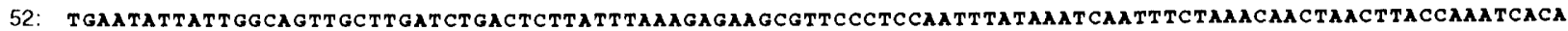

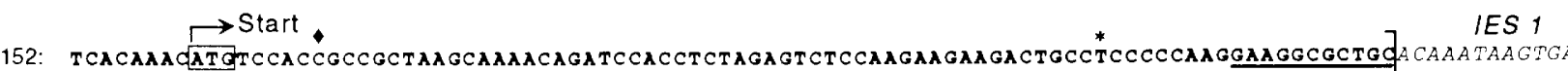

2 MDS 3 • IES 2

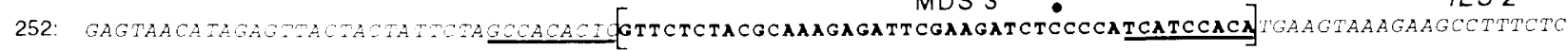
MDS 5

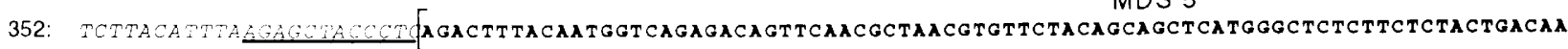

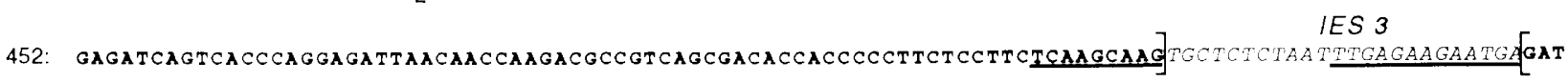
$\begin{array}{llllll}\text { MDS } 7 & \text { IES } 4 & \text { MDS } 9 & \text { IES } 5 & \end{array}$ 552: CTCCATTCTCCAGAACCTGA]AGTATTGAAATGAAATAAAAGGA]GCTTCAGGCCAAGTGTTCT] CTAAATAAGAACI [GGCGAGGTGTTAGAATCAGA

JES 6

652: TCAGCCACTTA CTTGCACTCGTAAGCATTACATCATTACAATTTGATTTGAGATTTTGAGAAGGCGCTGQCAAC

CAAGAAGTCCGACAAGGGTCACAAGGTAAG - intron * * * MDS 2

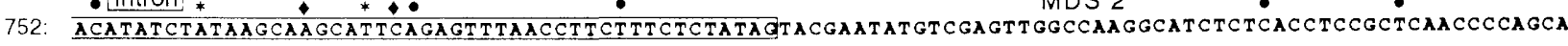

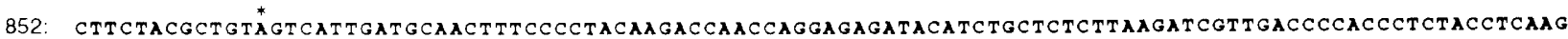

952: IES 7 MDS 4

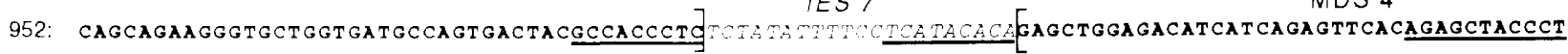
1052: G]CATACGAS 8 MDS 6 IES 9

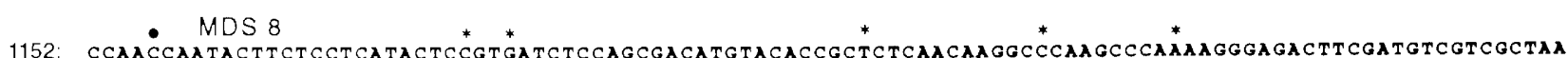

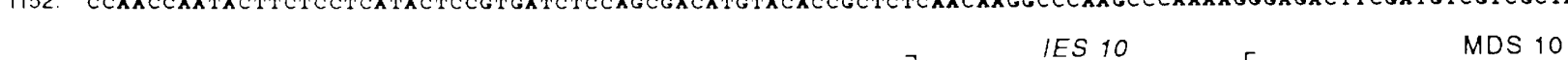

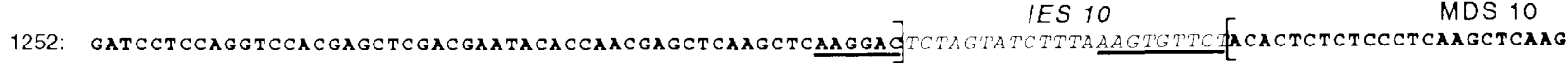
IES $11 \quad$ MDS $12 \quad$ IES 12

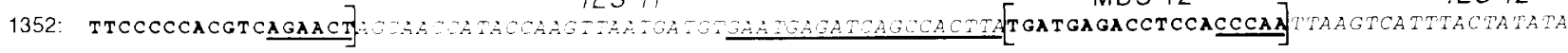
1452: ATGaATA

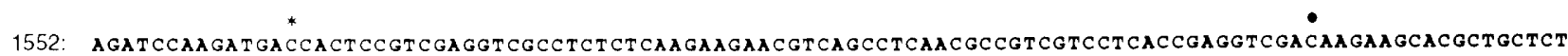

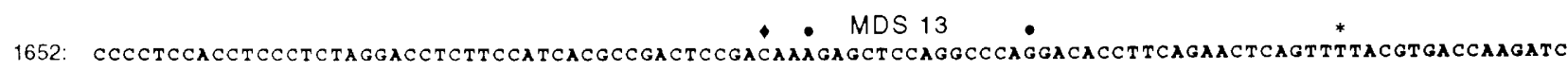

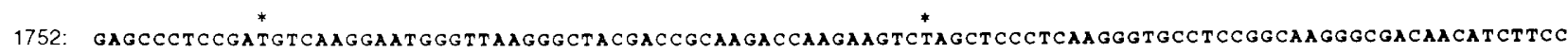

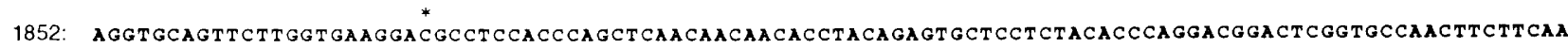

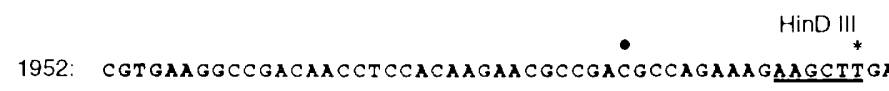

\section{2:} Stop. trailer $\longrightarrow$

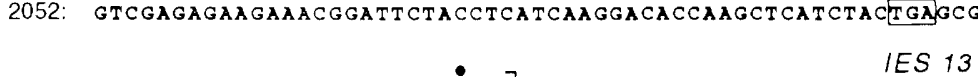

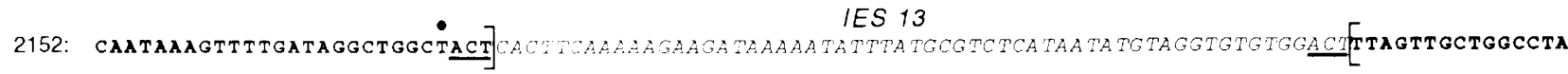

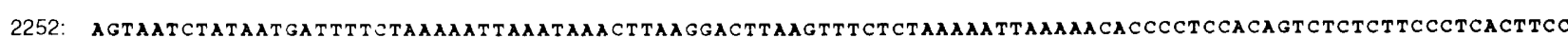

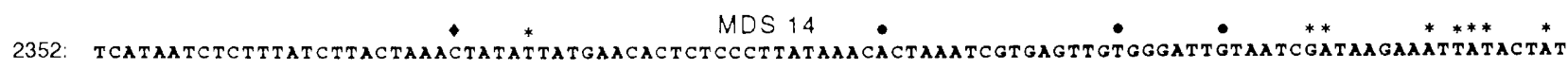

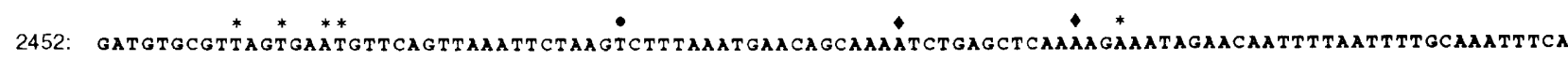

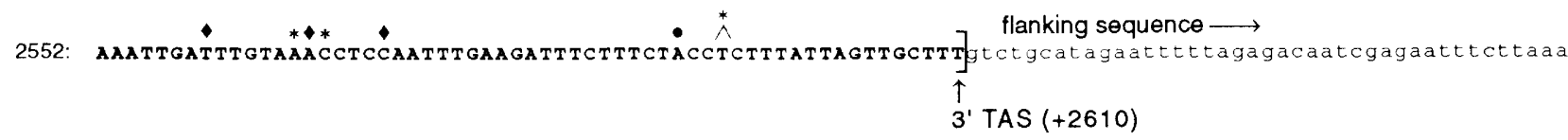

Figure 1. (See facing page for legend.) 


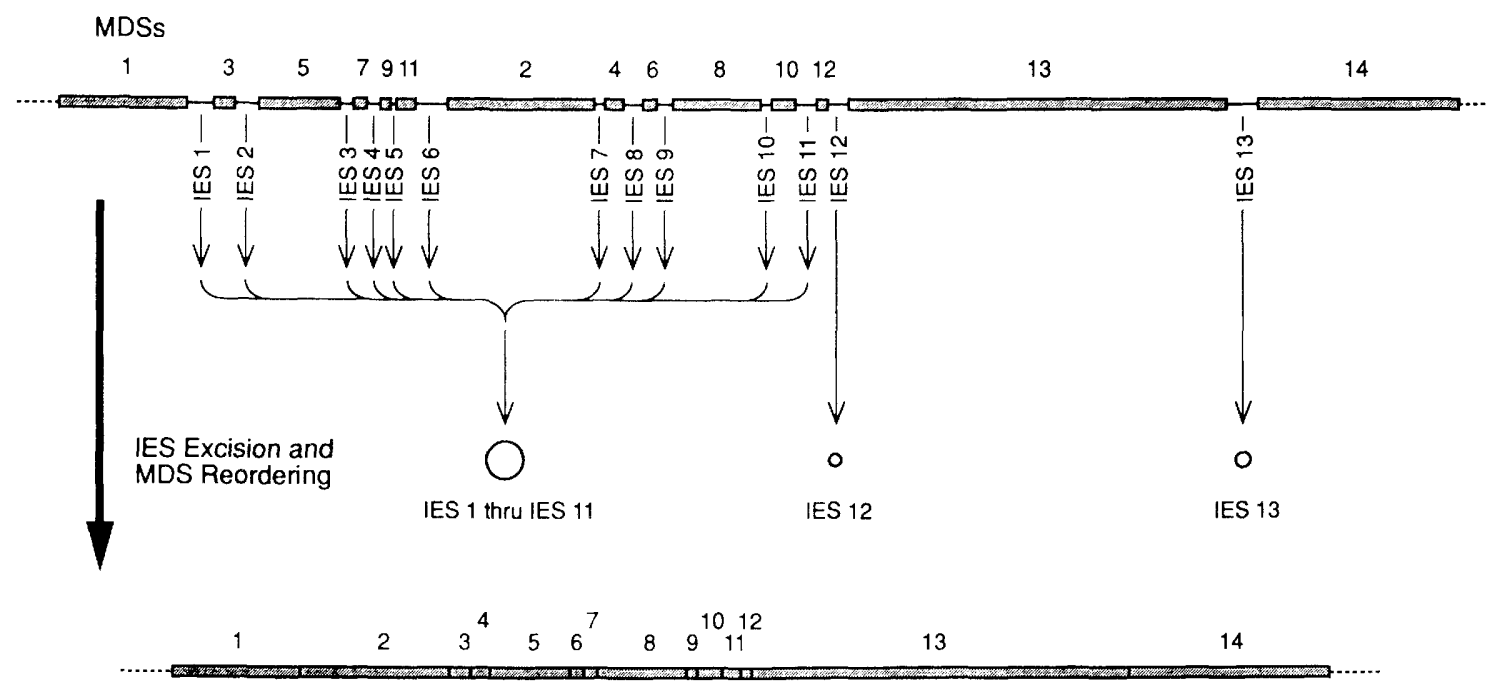

Figure 2. Schematic diagram of IES excision and MDS reordering of the micronuclear $\alpha$-TBP gene. (Top) A diagram of the micronuclear $\alpha$-TBP gene; (below) the unscrambled, spliced macronuclear gene. The shaded boxes are MDSs, the thin solid lines are IESs, and the dotted lines are flanking sequence. Excised IESs $1-11$ are shown as a large composite circle, and IESs 12 and 13 as small individual circles.

Total native macronuclear DNA from the recent exconjugant clone was analyzed by Southern hybridization. Lane 1 in Figure 3 contains uncut macronuclear DNA. Lanes 2, 3, and 4 contain macronuclear DNA cut with DraI, HindIII, or DraI plus HindIII, respectively. The blot was hybridized with the 1938-bp DraI fragment purified from the cloned macronuclear $\alpha$-TBP gene. Digestion with DraI alone (lane 2) produced a single hybridization signal in a 1938-bp fragment as expected for versions $\mathrm{S}, \mathrm{A}$, or $\mathrm{K}$. In addition to the bands expected for the $S$ and $A$ versions in every lane, bands predicted from HindIII digestion of a macronuclear $\mathrm{K}$ version were present in Figure 3, lanes 3 and 4. Cutting with HindIII alone produces three hybridization bands: one for a 2217 bp fragment for the S or A versions (same as uncut DNA in lane 1), one for a 1623-bp fragment, and a third band for a 594-bp fragment. The two smaller bands represent the two expected $\mathrm{K}$ fragments produced by HindIII digestion of the full-length $(2217-\mathrm{bp})$ macronuclear gene. The double digest with Dral/HindIII (lane 4) gives hybridization bands for a 1938-bp fragment, as expected for the $\mathrm{S}$ or A versions, and two more bands for 1344- and 436-bp fragments, as expected for the $\mathrm{K}$ version.

We did an identical Southern hybridization experiment with native macronuclear DNA from an O. nova clone that had not undergone detectable, successful conjugation in $>1500$ generations (data not shown). This culture was consistently grown at temperatures $16^{-}$ $25^{\circ} \mathrm{C}$ ) well above the necessary $12^{\circ} \mathrm{C}$ for exconjugant survival. Surviving exconjugants were never observed. The data from this Southern experiment is qualitatively identical to that with the exconjugant DNA /Fig. 3 and data not shown). Therefore, the Southern data show clearly that versions of the $\alpha$-TBP gene with and without a HindIII site are present in 3-week exconjugant macronuclear DNA and are also maintained in macronuclear DNA isolated after years of vegetative growth.

Sequencing of PCR products shows that the $K$ version of the $\alpha$-TBP gene is present in macronuclear DNA

Because the $\mathrm{K}$ version had only been found in cloned micronuclear DNA, we tested for the presence of $\mathrm{K}$ version in macronuclear DNA. Polymerase chain reactions (PCRs) of native macronuclear DNA were done with version-specific primers designed to amplify the $\mathrm{K}$ version but not the $S$ or A versions of the $\alpha$-TBP gene. The intron region of the $\alpha$-TBP gene located in MDS 2 (Fig. 1) was chosen for amplification because several differences between the $\mathrm{S}, \mathrm{A}$, and $\mathrm{K}$ versions are clustered in the intron. The pair of version-specific primers are identical in sequence to the $\mathrm{K}$ clone but differ in one or more nucleotide positions from the $S$ and A versions at the 3 ' ends of the primers (see Materials and methods). These mismatches bias the PCR strongly toward the use of the $\mathrm{K}$ version of the $\alpha$-TBP gene as template. The version-spe-

Figure 1. Nucleotide sequence of the micronuclear $\alpha$-TBP gene, K clone. The numbers at left correspond to the nucleotide sequence counting from the $5^{\prime}$ telomere addition site (TAS). The $5^{\prime}$ and $3^{\prime}$ TASs are indicated. MDSs are in boldface type and are bracketed; IESs are in italics. Direct repeats at the MDS/IES junctions are underlined. Translation start and stop codons are marked in their respective MDSs as they occur in the macronucleus. The symbols above the nucleotide sequence indicate base differences between the $\mathrm{K}$ version and the $S$ and A versions. ( $\downarrow$ ) Differences from A version; $(0)$ differences from S version; $(\star)$ differences from both $S$ and $A$ versions; $\left(\begin{array}{l}\star \\ *\end{array}\right)$ the base underneath is not present in the indicated clone. 

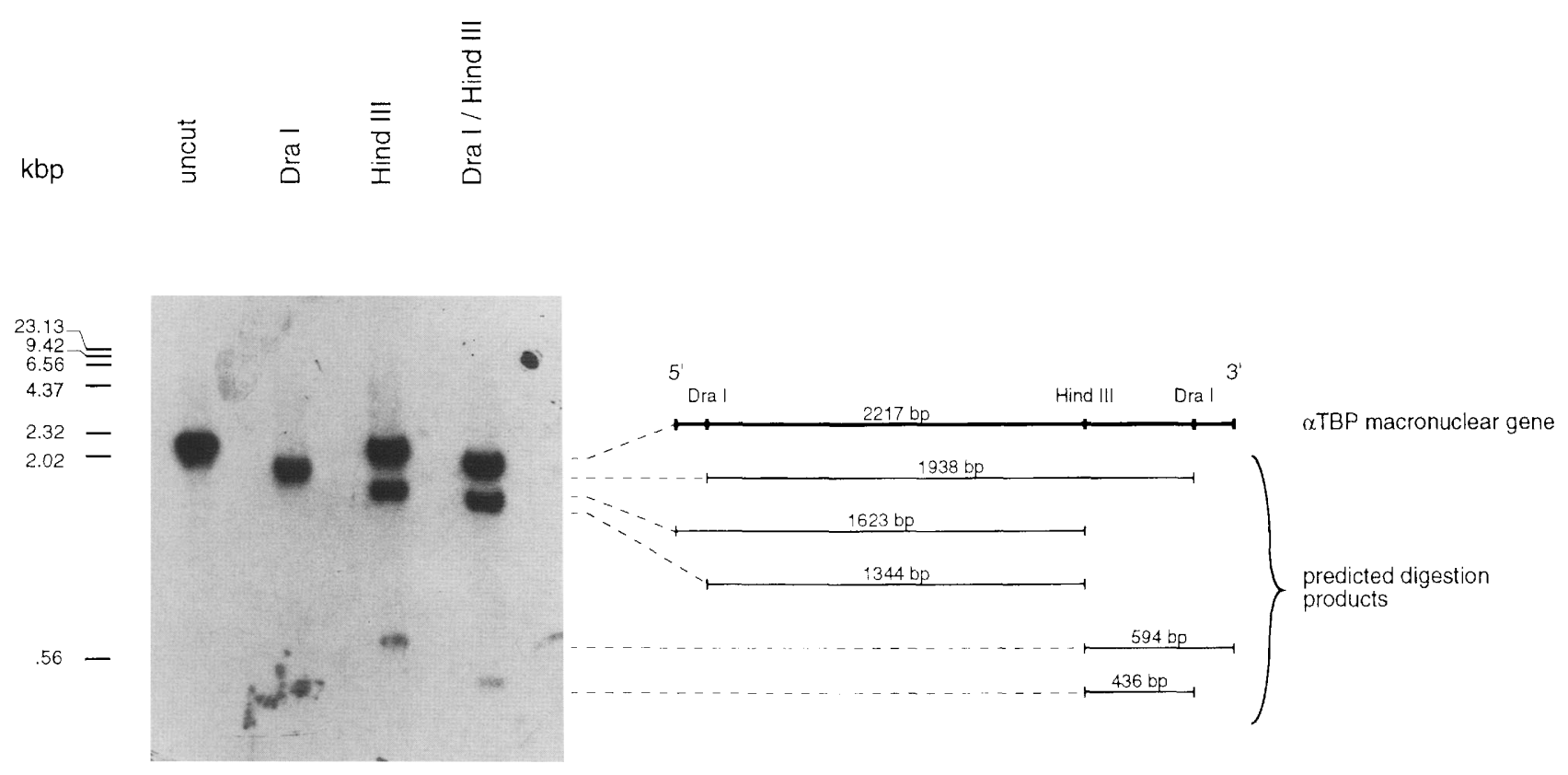

Figure 3. Southern blot of macronuclear DNA from a 3-week O. nova exconjugant clone testing for the presence of macronuclear $\alpha$-TBP genes with and without a HindIII site. A schematic diagram of the putative mac $\alpha$ K version of the 2217-bp $\alpha$-TBP macronuclear gene is shown on the right with its Dral and HindIII sites. The 1938-bp DraI fragment shown was used as probe. The predicted digestion products are shown below. (Left) Autoradiograph; the lanes (from left to right), are uncut macronuclear DNA, macronuclear DNA cut with DraI, macronuclear DNA cut with HindIII, and macronuclear DNA cut with both DraI and HindIII. Correspondence between autoradiographic bands and predicted fragments is indicated by the broken lines.

cific primer pair (VSFl/VSH3) and a nonversion-specific pair (P0190/M0870) that corresponds to all three known versions of the $\alpha$-TBP gene were used in PCR with total native macronuclear DNA (Fig. 4; for oligonucleotide sequences, see Materials and methods). The PCR products were sequenced directly using the 5'-amplification primer as the sequencing primer.

Figure $4 \mathrm{~A}$ shows the sequence of the intron region for all three versions, and Figure 4, B and C, compares the sequencing of amplification products generated with the version-specific PCR product and the nonversion-specific product, respectively (Fig. 4D is discussed in a following section). As expected, direct sequencing of amplification products generated with the version-specific primer pair clearly showed a sequence corresponding to the $\mathrm{K}$ version (as predicted by the mic $\alpha \mathrm{K}$ sequence) within the macronucleus (Fig. 4B). In addition, direct sequencing of amplification products obtained with the nonversion-specific primer pair showed the predicted sequence polymorphisms at nucleotide positions where the macronuclear versions $(\mathrm{S}, \mathrm{A}$, and $\mathrm{K})$ are known to differ (Fig. 4C). The expected nucleotides are indicated in Figure 4A. Reading $5^{\prime} \rightarrow 3^{\prime}$ (up the gell through the intron on the version-specific gel (Fig. 4B), the fourth indicated nucleotide (325) reads as a $T$, as expected for the $K$ version. The corresponding position on the nonversionspecific gel, showed bands in both the $G$ and $T$ lanes (Fig. $4 \mathrm{Cl}$. This was expected because the $\mathrm{S}$ and $\mathrm{A}$ versions have $G$ at that position, and the $K$ version has a $T$. Similar comparisons yielded the expected outcome at six other positions (see nucleotide numbers indicated in Fig. $4 \mathrm{~B}, \mathrm{C}$. The sequence of PCR products generated with the nonversion-specific $\alpha$-TBP primer pair agreed with results from similar amplification/sequencing experiments conducted in the intron region (J. Gray, pers. comm.). However, there are additional ambiguities, for example, at nucleotides 301 and 308 in Figure 4C, that are not accounted for by the three known versions. This suggests that there are other, as yet uncharacterized, versions of the $\alpha$-TBP gene in addition to the $S, A$, and $K$ versions.

The PCR products sequenced in this experiment were generated using native macronuclear DNA from an $O$. nova clone that had not undergone successful conjugation in $>1500$ generations. Sequencing of version-specific and nonversion-specific PCR products generated from the macronuclear DNA of a recent exconjugant clone yielded results identical to those shown in Figure $4, \mathrm{~B}$ and $\mathrm{C}$ (data not shown).

\section{Native micronuclear DNA contains only scrambled $\alpha$-TBP genes}

It is possible that nonscrambled versions of the $\alpha$-TBP gene exist within the micronucleus in addition to the scrambled versions. Such putative nonscrambled versions might then serve as precursors for the macronuclear $\alpha$-TBP genes, and the scrambled versions might simply be eliminated as useless sequences during macronuclear development. Therefore, we tested native micro- 

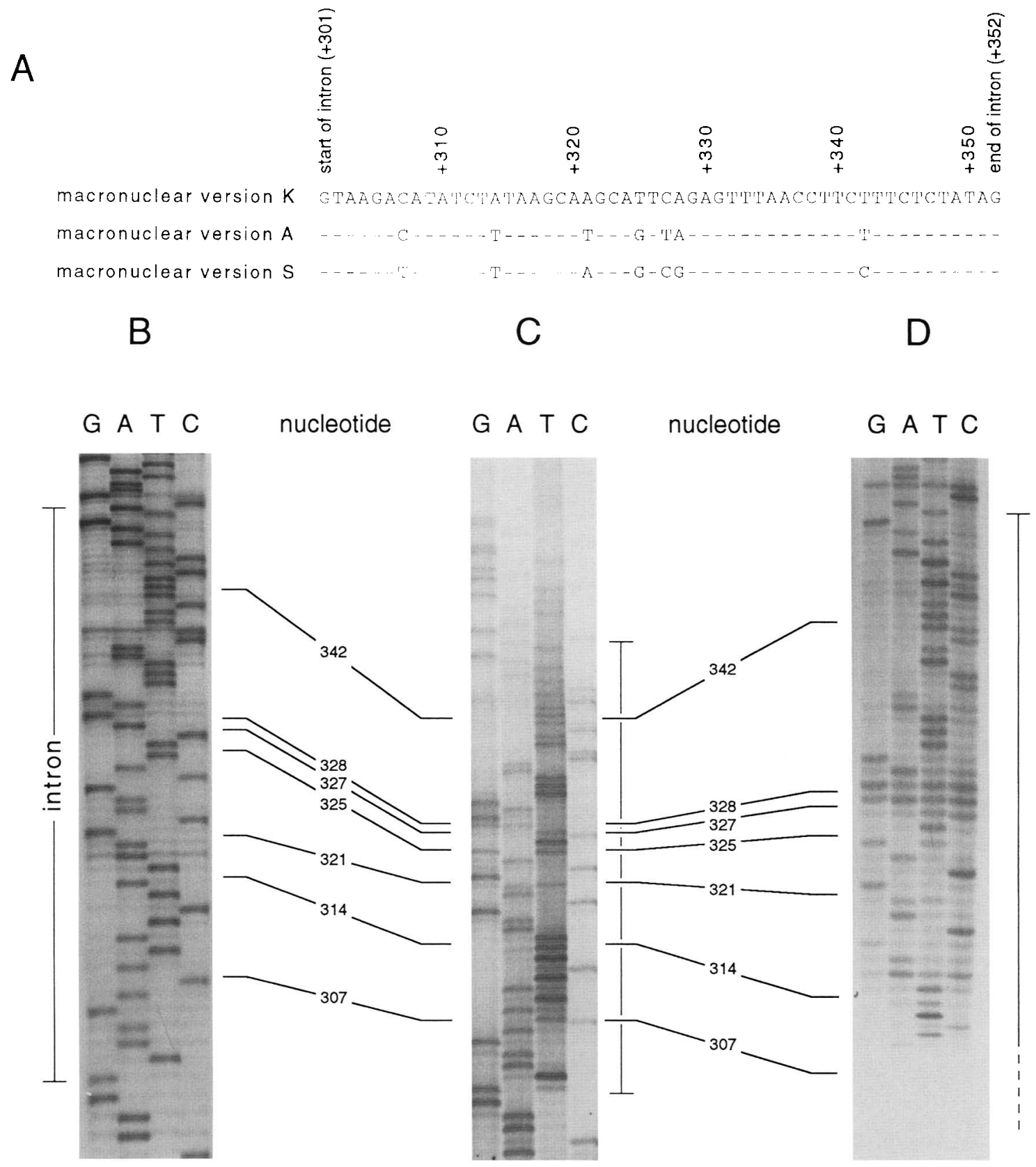

Figure 4. Sequence comparison between version K-specific PCR products and nonversion-specific PCR products generated from native macronuclear and micronuclear DNA. The predicted intron sequence for a $\mathrm{K}$ version of the macronuclear gene is shown in $A$ with differences between $K$ and the $A$ and $S$ vcrsions noted below. Sequencing of the intron region from PCR products is shown in $B-D$. $(B)$ Sequence of version K-specific macronuclear PCR products; $(C)$ sequence of nonversion-specific macronuclear PCR products; $(D)$ sequence of nonversion-specific micronuclear PCR products. (D) Gel missing the first indicated nucleotide (307). Corresponding positions on the gels are linked and labeled with the appropriate nucleotide number from $A$.

nuclear DNA by PCR for the presence of nonscrambled precursor genes encoding $\alpha$-TBP.

Four primer pairs were chosen that would yicld a PCR product from a nonscrambled gene that differed in size from the PCR product generated from a scrambled gene (Fig. 5A). Each primer pair was used with four different template DNAs: native macronuclear DNA (M), cloned mic $\alpha \mathrm{K} D N A(\mathrm{~K})$, a native micronuclear DNA prepara- tion $(\mu)$, and a sample of the same native micronuclear DNA preparation treated briefly with Bal 31 nuclease $\left(\mu^{\mathrm{T}}\right)$. Because of the high copy number of genes in macronuclear DNA, even a small contamination with macronuclear DNA can generate a background signal from nonscrambled genes in PCR analysis of a micronuclear DNA preparation. The short Bal 31 nuclease treatment of the micronuclear DNA preparation used as PCR tem- 
A

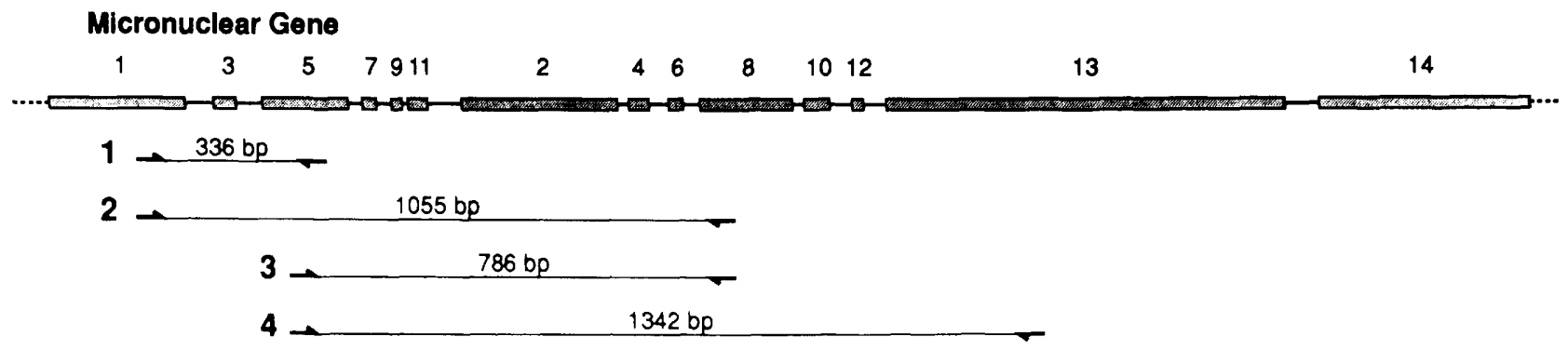

Macronuclear Gene

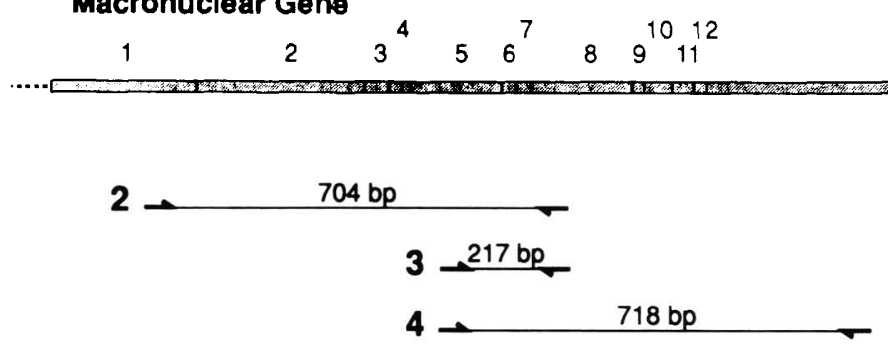

B

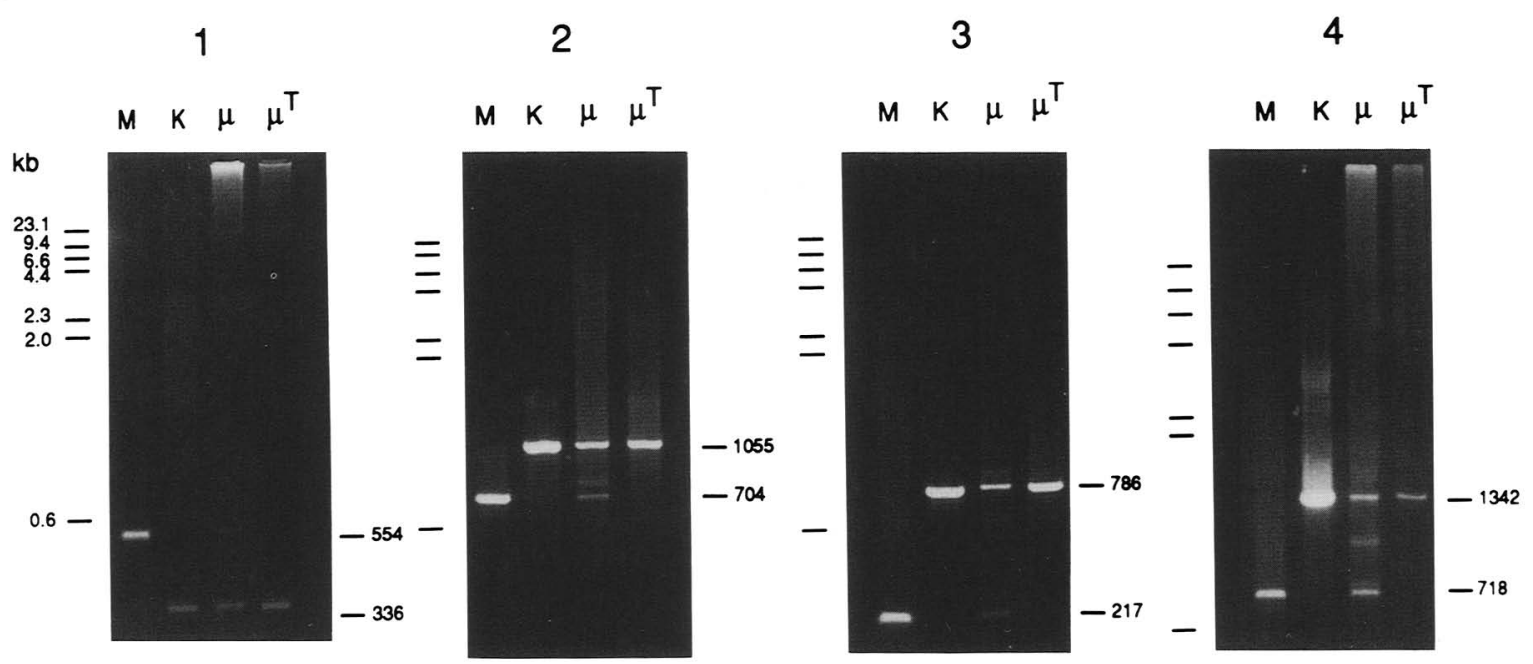

Figure 5. PCR test for the existence of a nonscrambled $\alpha$-TBP gene in the micronucleus. $|A|$ Schematic diagrams of the scrambled (top) and nonscrambled (bottom) genes are shown. MDSs are indicated by shaded boxes, and IESs by thin solid lines. Primer positions (heavy half arrows) and expected products (thin lines connecting arrows) for scrambled and nonscrambled genes are indicated for four different primer pairs (1-4). All primer pairs were used in PCRs with four different template DNAs. $(B)$ Gel 1 shows PCR products for primer pair 1, gel 2 for primer pair 2, etc. Locations of $\lambda$ HindIII markers are indicated at left of each gel. (Lanes $M$ ) PCR products obtained when native macronuclear DNA is used as template; (lanes KIPCR products obtained when mic $\alpha$ K clone DNA is used as template; (lanes $\mu$ ) PCR products from amplification of an untreated native micronuclear DNA preparation; (lanes $\mu^{\mathrm{T}}$ ) PCR products from amplification of Bal 31-treated micronuclear DNA preparation.

plate was intended to remove the low-molecular-weight, contaminating macronuclear DNA. Figure 5B shows four sets of agarose gels in which PCR products obtained with the four sets of primers $(1-4)$ and the four types of template DNAs were run $\left(M, K, \mu, \mu^{\mathrm{T}}\right)$.

Primer pair 1 generated a 554-bp product when a ma- cronuclear (unscrambled) template (Fig. 5B, gel 1, lane M) was amplified, and a 336-bp product when a cloned, micronuclear scrambled template (lane $\mathrm{K}$ ) was amplified. Lane $\mu$ shows both bands, reflecting the presence of unscrambled and scrambled $\alpha$-TBP genes in the micronuclear DNA preparation used as template. However, am- 
plification of the same micronuclear DNA preparation (lane $\mu^{\mathrm{T}}$ ) after Bal 31 treatment to remove contaminating macronuclear DNA generated only the 336-bp product, showing that only a scrambled version of the gene was present in high-molecular-weight, native micronuclear DNA. Primer pairs 2-4 yielded the same qualitative results as primer pair 1 (Fig. $5 \mathrm{~B}$ ). These data strongly suggest that the micronuclcus contains only $\alpha$-TBP genes scrambled in the same way as the micronuclear mic $\alpha \mathrm{K}$ clone.

In addition to the PCR assay, we tested for the presence of nonscrambled $\alpha$-TBP genes in the micronucleus by Southern hybridization. Digestions with four different pairs of enzymes clearly indicated that only $\alpha$-TBP genes in the scrambled configuration seen in the mic $\alpha \mathrm{K}$ clone are present in micronuclear DNA (data not shown).

Sequencing of additional micronuclear $\alpha$-TBP gene clones and micronuclear PCR products

It is possible that the short treatment with $\mathrm{Bal} 31 \mathrm{nu}-$ clease described in the previous section was responsible for the destruction of a nonscrambled version of the micronuclear $\alpha$-TBP gene present very near the end of a micronuclear chromosome. If this were the case, then such a nonscrambled version of the gene would have escaped detection in our PCR assay. Acknowledging this possibility, we did a second extensive screen of the $O$. nova micronuclear library to search for $\alpha$-TBP micronuclear clones containing a nonscrambled arrangement of MDSs. Previously, we had isolated four elones in the original screen of the micronuclear library. Using the large 1938-bp Dral fragment of the macronuclear gene as a probe, we screence $1.2 \times 10^{6}$ plaques from the micronuclear library, which is the DNA equivalent of $\sim 14$ times the micronuclear genome complexity. From the second round of screening we purified 15 additional clones. These were analyzed by PCR with the same strategy used in PCR amplification of native micronuclear DNA using primer pairs 2,4 , and others (Fig. 5A and data not shown). All 15 clones generated the products expected for a scrambled micronuclear $\alpha$-TBP gene (data not shown). Four of the isolated $\alpha$-TBP micronuclear gene clones contained a completc $\alpha$-TBP precursor gene, and 11 of the clones contained incomplete $\alpha$-TBP genes. Even for these incomplete clones the PCR analysis confirmed that the partially rcpresented gene was scrambled in the same pattern as the other complete clones (data not shown).

All 19 purified $\lambda$ clones were sequenced directly using a primer that yielded a sequence in the $3^{\prime}$-noncoding region of the gene, where many sequence differences made it easy to distinguish between the three known versions of the gene (Fig. 1). All clones corresponded to the mic $\alpha \mathrm{K}$ version (data not shown).

We tested directly for the presence of other versions of the $\alpha$-TBP gene in the micronucleus by sequencing PCR products generated using native micronuclear DNA as template. The resulting sequence is shown in Figure 4D. The indicated bases show the same nucleotide polymorphisms as those observed within the sequence of the nonversion-specific PCR products (Fig. 4C). This would indicate that $\mathrm{S}$ and $\mathrm{A}$, as well as $\mathrm{K}$, versions of the $\alpha$-TBP gene are present in native micronuclear DNA. Though base 307 is not present in this loading of the sequencing gel, other loadings clearly show the expected C/T-base polymorphism (data not shown).

The failure to clone $\mathrm{S}$ or A versions could be because our O. nova micronuclear library is not representative of the total micronuclear genome. Perhaps the $\mathrm{S}$ and A versions were not originally included or were not amplified during later amplification of the library. This seems to be the most likely explanation in light of the Southern data obtained with recent exconjugant macronuclear DNA (Fig. 3) and the sequencing of PCR products from native micronuclear DNA (Fig. 4D). Southern hybridization indicated that $\alpha$-TBP macronuclear genes with and without the distinguishing HindIII restriction site are present in macronuclear DNA from the new exconjugant clone (Fig. 3). The presence of versions without a HindIII site in addition to the presence of the $\mathrm{K}$ version in recent exconjugant DNA indicates that $S$ and/or A versions did not arise in macronuclei during years of vegetative growth but must have been generated from micronuclear $\mathrm{S}$ and $\mathrm{A}$ precursors. In addition, direct sequencing of $\mathrm{PCR}$ products generated from native micronuclear DNA clearly shows the presence of $S, A$, and $K$ versions in the micronucleus (Fig. 4D). Therefore, the $S$ and A precursors must have escaped inclusion or detection in the micronuclear library.

\section{Discussion}

\section{Scrambled pattern of the $\alpha$-TBP gene}

The micronuclear $\alpha$-TBP gene is scrambled in a patterned array in which most of the MDSs occur in an odd-numbered group, 1-3-5-7-9-11, and an even numbered group, 2-4-6-8-10-12, followed by 13 and 14 . Thus, 11 of the MDSs are disordered in a regular pattern followed by the nonscrambled MDSs 12-13-14. This configuration contrasts sharply with the apparently random arrangement of MDSs in the actin I gene in O. nova (Greslin et al. 1989). In the micronuclear actin I gene, nine MDSs occur in the scrambled order 3-4-6-5-7-9-2-18. Furthermore, MDS 2 is in the inverted configuration, so that inversion is required during unscrambling to correctly splice MDS 2 with MDS 1 and MDS 3 . None of the MDSs in the $\alpha$-TBP gene are inverted. In addition, the $5^{\prime}$ and $3^{\prime}$ telomere addition sites (TASs) of the scrambled actin I gene are buried within the gene on either side of the inverted MDS 2. However, the $5^{\prime}$ and $3^{\prime}$ TASs of the micronuclear $\alpha$-TBP gene are present at the ends of the scrambled gene in MDSs 1 and 14, respectively, and do not require reordering of MDSs to make them available for telomere addition after excision of the gene from the chromosome. 
A recombination model for unscrambling of the micronuclear $\alpha$-TBP gene

The structure of the micronuclear $\alpha$-TBP gene itself suggests that unscrambling could be achieved by homologous recombination. At each MDS/IES junction is a scquence (Table 1) that is repeated in a direct orientation at another MDS/IES junction. We propose that recombination between the two copies of the repeat within the same DNA molecule guides the intramolecular splicing of MDSs into the correct order. During the 13 recombination events that accomplish splicing of the 14 MDSs, one member of each pair of repeats is retained in the splicing junction between MDSs and one copy is presumed to be excised with its IES. For nonscrambled MDSs in any gene (MDSs 12,13, and 14 in the micronuclear $\alpha$-TBP gene), the intramolecular recombination model requires only a looping out of the intervening IES to allow alignment of direct repeats for recombinatorial splicing of the two flanking MDSs (e.g., Fig. 6, IES 12 and 13). In contrast, reordering of scrambled MDSs by recombination requires splicing between MDSs that may be separated by intervening DNA containing multiple IESs and MDSs. In the scrambled part of the micronuclear $\alpha$-TBP gene each direct repeat is separated from its partner by an average of nine MDSs and IESs. Alignment of the two partners in every pair of repeats causes the stretch of micronuclear DNA containing the micronuclear $\alpha$-TBP genc to fold into the configuration shown in Figure 6, where the pairing up of the 13 pairs of repeat sequences is identified by $\times \mathrm{s}$. Recombination events at the $\times$ s would splice the 14 MDSs into the unscrambled order. If all recombination events occur according to the model, IESs $1-11$ would be excised from the gene as a single, circular molecule containing one member of each of the 11 repeat pairs (Fig. 2B). IESs 12 and 13 would be excised as two separate circular molecules (Fig. 2B). IESs 12 and 13 are 37 and 58 bp long, respectively, and could only bend into a circle if modified or assisted in some unknown way.
As in the actin I gene, those repeats that direct unscrambling of MDSs in the $\alpha$-TBP gene are longer than those that direct the joining of nonscrambled MDSs isee Table 1). The 11 pairs of repeats in the scrambled region of the $\alpha$-TBP gene range from 6 to $19 \mathrm{bp}(9-13 \mathrm{bp}$ in the scrambled region of the actin I gene). In the nonscrambled region of the $\alpha$-TBP gene, the repeats are 5 and $3 \mathrm{bp}$ $14 \mathrm{bp}$ for the two nonscrambled MDSs in the actin I gene). In nonscrambled genes, repeats at MDS/IES junctions range from 2 to $6 \mathrm{bp}$ (Klobutcher and Jahn 1991).

Mechanisms other than intramolecular homologous recombination for unscrambling are possible. IES removal in another hypotrich, Euplotes crassus, is known to occur after the micronuclear chromosomes have polytenized (Tausta and Klobutcher 1989). If IES removal and MDS unscrambling and rejoining in O. nova occur after polytenization, recombination might be intermolecular instead of intramolecular (for an intramolecular model, see Fig. 6). Intermolecular recombination would require regulatory mechanisms to prevent the generation of a high frequency of spurious recombination products.

Unscrambling as well as removal of IESs from nonscrambled genes might also be accomplished through RNA intermediates. Elimination of IESs, reordering, and splicing of MDSs could occur in RNA form, followed by reverse transcription to make the DNA copy of the macronuclear genes. However, genic processing based on RNA intermediates would require two regulatory mechanisms for RNA synthesis, one for generating the RNA intermediate of a gene and one for subsequent generation of mRNA transcripts from the DNA copy of the gene. In addition, for genes like the actin I gene that have one or more MDSs in the opposite polarity, both strands of the DNA would need to be transcribed and trans-splicing would be required to generate RNA templates for reverse transcription. The complexities engendered by production and processing of RNA in RNA-based models make such models improbable. Furthermore, the DNA recombination model for IES removal is supported strongly by the demonstration that IESs in the hypotrich E. crassus

Table 1. Direct repeats at MDS/IES iunctions in the micronuclear $\alpha$-TBP gene

\begin{tabular}{|c|c|c|}
\hline Left MDS/IES junction & MDS & Right MDS/IES junction \\
\hline 5' telomere addition site & 1 & GA AGGCGCTGC \\
\hline GAAGGCGCTGC & 2 & GCCACECTC \\
\hline GCCACACTC & 3 & TCA T $\subseteq$ CACA \\
\hline TCATA $\bar{C} A C A$ & 4 & $\mathrm{AGAG} \overline{\mathrm{C}} \mathrm{TACCCTC}$ \\
\hline 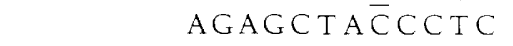 & 5 & TCA A GCAAG \\
\hline TCAAGAAG & 6 & T T GAGAAGA A $\subseteq G A$ \\
\hline TTGAGAAGAAGA & 7 & AGAACCTGA \\
\hline AGAACCTGA & 8 & A A GGAC \\
\hline AAGGAC & 9 & A A G T G T T C T \\
\hline A AGTGTTCT & 10 & $\mathrm{AGAACT}$ \\
\hline AGAACI & 11 & GAATCAGATCAGCCACTTA \\
\hline GAATGAGATCAGCCACTTA & 12 & $\mathrm{CCCA} \overline{\mathrm{A}}$ \\
\hline $\mathrm{CCCAA}$ & 13 & $\mathrm{ACT}$ \\
\hline $\mathrm{ACT}$ & 14 & $3^{\prime}$ telomere addition site \\
\hline
\end{tabular}

The sequences of the 13 pairs of direct repeats at MDS/IES junctions in the micronuclear $\alpha-T B P$ gene are shown. Underlined nucleotides indicate base-pair mismatches between repeats. 


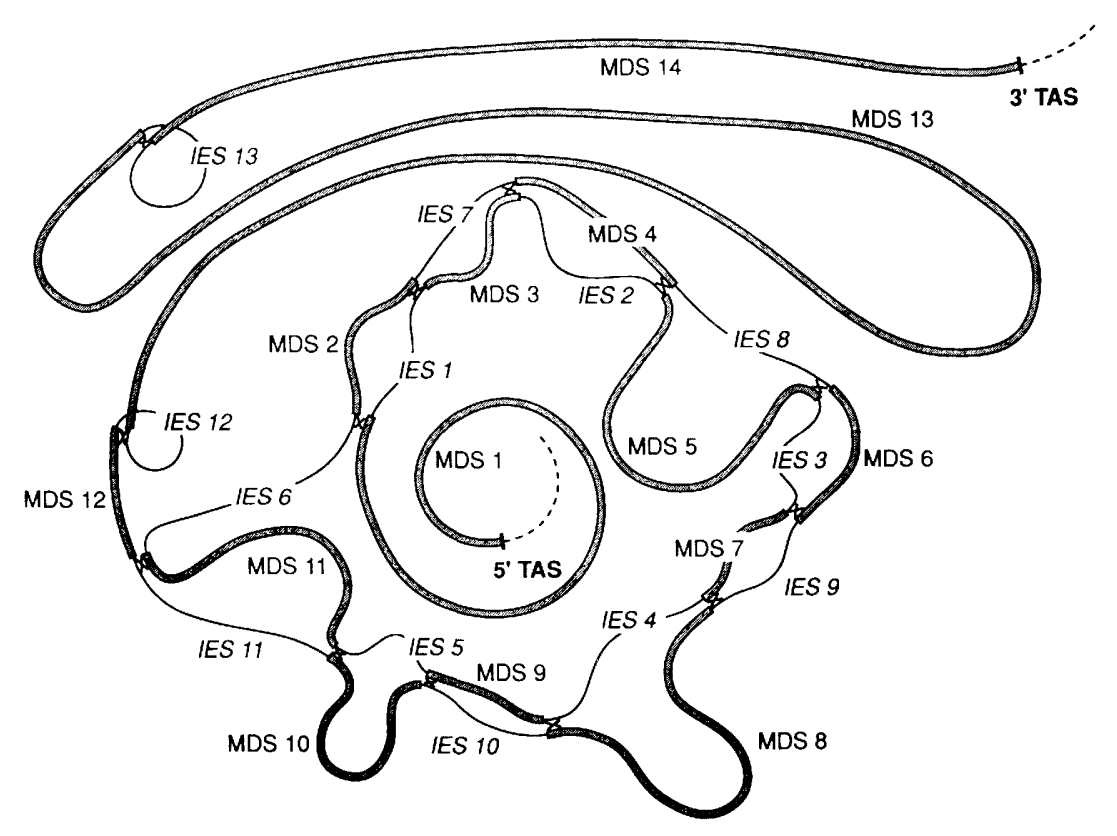

Figure 6. A recombination model for unscrambling of the micronuclear $\alpha$-TBP gene. A schematic diagram of DNA folded so that the 13 pairs of direct repeat sequences are aligned (at $\times$ s). The $5^{\prime}$ TAS with flanking DNA (broken line) is in the center; 3' TAS with flanking DNA is in the upper right. The shaded boxes are MDSs; the thin solid lines are IESs. appear as free circular DNA molecules in the late polytene chromosome stage (Tausta and Klobutcher 1989). The sequence in the region where the ends of the IES are joined indicates that in E. crassus, the IES is disjoined from its flanking MDSs by staggered cuts, which also rules against RNA models of gene processing in hypotrichs (Tausta et al. 1991).

Are nonscrambled versions of the $\alpha$-TBP gene present in the micronucleus?

It is conceivable that the micronucleus of O. nova contains nonscrambled versions of the $\alpha$-TBP gene that give rise to the $S, A$, and $K \alpha$-TBP genes in the macronucleus. Scrambled $\alpha$-TBP genes in the micronucleus might be functionless, nonprocessed genes that are eliminated during macronuclear development. The correspondence of the scrambled and unscrambled sequences of the actin I and $\alpha$-TBP genes argue against this. It is highly improbable that the scrambled micronuclear actin I gene would have been maintained with perfect theoretical "instructions" for unscrambling and without introduction of a single mutation in the leader, trailer, or coding region of the gene, unless the scrambled form of the gene were essential to production of the unscrambled macronuclear gene. Without selective pressure to maintain its sequence, the scrambled actin I gene should have diverged over time. Instead, when the IESs and one member of each pair of repeats are removed from the scrambled actin I gene, according to the homologous recombination model, the product perfectly matches the macronuclear actin I sequence (Greslin et al. 1989).

Similarly, it seems highly unlikely that the scrambled $\alpha$-TBP gene would be maintained with such high fidelity in the absence of selective pressure. By Southern blot hybridization and sequencing of version-specific PCR products, we can detect a macronuclear gene corresponding to our sequenced micronuclear $\alpha$-TBP gene (Figs. 3 and 4). In addition, if the recombination events specified in the model are executed, the scrambled gene is capable of producing a functional $\alpha$-TBP macronuclear gene. We searched for a nonscrambled $\alpha$-TBP gene in the micronuclear DNA library, and among 19 positive clones we did not find any that were nonscrambled. Scrambled genes could be mutated nonfunctional artifacts that accumulate in organisms such as $O$. nova that have not mated and undergone macronuclear development successfully. However, mating and survival recently have been achieved in O. nova by selfing, proving that scrambled genes are not incompatible with successful macronuclear development. Finally, because the PCR assay (Fig. 5) and Southern hybridization of micronuclear DNA (data not shown) did not detect nonscrambled forms of the gene in the micronucleus it seems very likely that scrambled $\alpha$-TBP genes serve as the true precursors of the macronuclear $\alpha$-TBP genes.

\section{IESS}

Organization of genes into MDSs and IESs is a general feature of the micronuclear DNA in hypotrichs. Fifteen hypotrich micronuclear genes, including the $\alpha$-TBP gene, have been characterized by restriction endonuclease mapping and/or sequencing: in $O$. nova (Klobutcher et al. 1984; Ribas-Aparicio et al. 1987; Greslin et al. 1989); in O. fallax (Herrick et al. 1987); in E. crassus (Baird et al. 1989; Tausta et al. 1991); and in Stylonychia lemnae (Bierbaum et al. 1991). With one uncertain exception in 
E. crassus (Baird et al. 1989), all of these micronuclear genes contain IESs.

There are few clues to the evolutionary origin, functional significance (if any), or mechanism of removal of IESs. IESs are unique sequences and are $\mathrm{A} / \mathrm{T}$ rich compared with MDSs. Some IESs interrupt regions $5^{\prime}$ or $3^{\prime}$ to the coding regions of the macronuclear genes, but others occur within amino acid-coding regions, and excision to the precise base pair is essential to maintain coding function. They are short, ranging in size from 14 to 548 bp (Klobutcher and Jahn 1991). The IESs in the micronuclear $\alpha$-TBP gene range from 14 to $59 \mathrm{bp}$ in length. Some IESs (but none of those in the $\alpha$-TBP genel contain very short, usually imperfect, A/T-rich inverted repeat sequences near their ends. The presence of these inverted repeats has led to the suggestion that IESs may be degenerate versions of transposable elements $\{$ Klobutcher and Jahn 1991). At least some species of hypotrichs do contain many hundreds of copies of transposon-like elements (Hunter et al. 1989; Tausta et al. 1991), which might have served as the evolutionary progenitors of IESs. These transposon-like elements, like some IESs, have 2-or 3-bp direct repeat sequences at their ends, but they are many times longer than IESs ( 4 and $5.3 \mathrm{~kb}$ ). All copies of the transposon-like elements in E. crassus are eliminated early in polytene chromosome development and many hours before IES excision begins (Baird et al. 1989; Jahn et al. 1989; Krikau and Jahn 19911. Overall, the similarity between IESs and transposon-like elements is slight, and the idea of an evolutionary connection between the two is, at present, tenuous.

So far, IESs in hypotrichs can be divided into two types, as defined by the nature of the MDSs that they separate. Type-I IESs are interposed between MDSs that are in a nonscrambled order and have 2- to 6-bp direct repeats that flank the IES at its MDS/IES iunctions. Type-II IESs separate scrambled MDSs and have 6- to 19 -bp repeats at their MDS/IES junctions. Direct repeat sequences of type-II IESs are not located at the two ends of the IES as in type-I IESs. Instead, pairs of repeat sequences are present whose two members are distributed according to the pattern of scrambling of MDSs (Fig. 1; Table 1). For example, in the micronuclear $\alpha$-TBP gene, the junction of IES 1 with MDS 1 contains the sequence $5^{\prime}$-GAAGGCGCTGC-3'. This sequence is not repeated at the other end of IES 1 (the junction with MDS 3 ) in the scrambled gene (Figs. 1 and 2 ) but is repeated at the junction of IES 6 with MDS 2 in anticipation of splicing MDS 1 to MDS 2 in the final macronuclear gene. This arrangement of repeat pairs is the basis of the recombination model of unscrambling described above. The repeat sequences for type-II IESs are also generally longer (6-19 bp) than for type-I IESs $(2-6 \mathrm{bp})$. As in type-I IESs, one copy of each repeat sequence is retained in an MDS and the other is excised with the IES. Type-II IESs may have derived from type I, assuming that IESs were present before MDS scrambling occurred in evolution. In the micronuclear $\alpha$-TBP gene, IESs 1-11 (separating scrambled MDSs) are type II and IESs 12 and 13 (separating nonscrambled MDSs) are type I.

\section{Evolution of gene scrambling}

None of our observations on the scrambling of the actin I and $\alpha$-TBP genes has given us more than vague clues about the possible purpose, significance, or evolution of scrambling. Perhaps scrambling is "allowed" in the micronucleus because transcription of micronuclear genes is not necessary for cell growth and reproduction. In addition, IES introduction might, in some way, be connected with the transcriptional silencing of the micronucleus. Scrambling might then have ensued after IES introduction, as selective pressure to maintain transcriptionally functional genes was removed.

The evolution of a scrambled gene may require the prior existence of IESs in the gene; the two examples of scrambling characterized so far both contain IESs. Models of scrambling are possible without IESs but not without pairs of repeated sequences. Because IESs are present in all or nearly all hypotrich micronuclear genes, including nonscrambled genes, we suggest that IESs evolved before scrambling and that the evolution of scrambling required the prior existence of IESs. Recombination between existing type-I IESs (separating nonscrambled MDSs) could create scrambling. Instructions for unscrambling, consisting of increased length of the repeat sequences at MDS/IES junctions, would need to precede or coevolve with MDS scrambling. The molecular machinery for unscrambling, of which we know essentially nothing, presumably existed prior to the evolution of scrambling, perhaps as the machinery that splices out type-I IESs. Type-I IESs in E. crassus (Tausta et al. 1991) are spliced by a machinery that produces staggered cuts in the DNA at MDS/IES junctions. It will be useful to know whether staggered cuts are made in the removal of type-I and type-II IESs and splicing of MDSs in O. nova.

The arrangement of MDSs in odd- and even-numbered series in the $\alpha$-TBP gene may be a clue to the evolution of scrambling. Folding of the chromatin DNA containing the original nonscrambled $\alpha$-TBP gene may well have brought sequences into juxtaposition, which then governed recombination between pairs of type-I IESs to produce the patterned array of type-II IESs and scrambled MDSs in the contemporary $\alpha$-TBP gene.

\section{Materials and methods \\ Cell culture, isolation of nuclei, and native genomic DNA preparation}

O. nova cultures were grown and harvested as in Prescott and Greslin (1992). Nuclei were isolated, and native macronuclear and micronuclear genomic DNA was prepared according to Prescott and Greslin (1992).

\section{Cloning and sequencing}

A micronuclear library (Klobutcher et al. 1984) was screened using a 1938-bp restriction fragment generated by DraI digestion of a macronuclear clone of $\alpha$-TBP, pMAC-56A /Gray et al. 1991). Two different fragments were subcloned from mic $\alpha \mathrm{K}$, a positive $\alpha$-TBP micronuclear clone. A HindIII fragment of $\sim 2100$ bp was subcloned into the vector pGEM $7 \mathrm{zf}^{+}$(Promega) 
to form pmic56K-H3. pmic56K-H3 proved to be an incomplete clone, so another subclone from mic $\alpha \mathrm{K}$ was generated with a NheI-SpeI restriction fragment of $\sim 4200$ bp and pGEM $7 \mathrm{zf}^{+}$ (pmic56K-N/S). Sequence was obtained by the dideoxynucleotide chain-termination method using Sequenase (U.S. Biochemical Corp.) and $\left[\alpha^{-35}\right.$ S $]$ dATP incorporation according to the manufacturer's instructions.

Subsequent screens of the micronuclear library were conducted identically. The additional isolates were analyzed directly by sequencing of the $\lambda$ clone DNA. Ten micrograms of the clone DNA was first digested with either AseI or EcoRV (New England Biolabs) and then extracted once with phenolchloroform and once with chloroform, and then ethanol-precipitated. The precipitate was resuspended in $8 \mu l$ of $1 \times$ Sequenase reaction buffer (U.S. Biochemical Corp.). Forty units of T7 gene 6 exonuclease (U.S. Biochemical Corp.) was added, and the rcaction was incubated at $30^{\circ} \mathrm{C}$ for $2 \mathrm{hr}$ (Straus and Zagursky 1991). The T7 gene 6 exonuclease was heat inactivated by incubation at $95^{\circ} \mathrm{C}$ for $6 \mathrm{~min}$ and then quickly chilled on ice. Sequencing then proceeded according to the manufacturer's instructions using $\left[\alpha^{-{ }^{35}} \mathrm{~S}\right] \mathrm{dATP}$ incorporation.

PCR products were sequenced essentially in the same way as the $\lambda$ clones, except there was no digestion with a restriction enzyme prior to treatment with the T7 gene 6 exonuclease. Sequencing with Sequenase and $\left[\alpha^{-35}\right.$ S $]$ dATP incorporation was according to the manufacturer's instructions. The sequencing reactions were resolved in a denaturing $10 \%$ polyacrylamide gel.

\section{Southern hybridization}

Native $O$. nova macronuclear DNA from a new exconjugant clone was digested with DraI, HindIII, and DraI-HindIII (Stratagene) at $37^{\circ} \mathrm{C}$ for $2 \mathrm{hr}(1 \mu \mathrm{g}$ of DNA per digest, $25-50$ units of enzyme) in $50 \mu \mathrm{l}$ of $10 \mathrm{~mm}$ Tris- $\mathrm{HCl}(\mathrm{pH} 7.9), 10 \mathrm{mM} \mathrm{MgCl}_{2}, 50$ $\mathrm{mm} \mathrm{NaCl}, 1 \mathrm{~mm}$ DTT, and $100 \mu \mathrm{g} / \mathrm{ml}$ of BSA (New England Biolabs, buffer 2). One microgram of undigested macronuclear DNA was suspended in $50 \mu \mathrm{l}$ of the same buffer. Twenty-five microliters of the undigested DNA and $25 \mu 1$ of each digest were then run directly in a $1.0 \%$ agarose gel containing $0.1 \mu \mathrm{g} / \mathrm{ml}$ of ethidium bromide and $1 \times$ TBE buffer at $100 \mathrm{~V}$ for $3 \mathrm{hr}$. DNA was transferred to nylon Zetabind membrane with $0.4 \mathrm{M} \mathrm{NaOH}$ on a capillary blotting apparatus for $16 \mathrm{hr}$ at room temperature. Fifty nanograms of the large DraI fragment (1938 bp; see Fig. 3) from the cloned macronuclear $\alpha$-TBP genc (pmac-56A; Gray et al. 1991) was labeled by random primer extension with Klenow (Promega). Unincorporated radiolabeled TTP was removed by passage of the kinase reaction mix over a G-50 Sepharose column $\left(5^{\prime}-3^{\prime}\right.$, Inc.). The blot was prehybridized for $5 \mathrm{hr}$ at $65^{\circ} \mathrm{C}$ in $1 \mathrm{M} \mathrm{NaCl}, 50 \mathrm{~mm}$ Tris- $\mathrm{HCl}(\mathrm{pH} 8.0), 1 \mathrm{~mm}$ EDTA, $10 \times$ Denhardt's solution, $0.1 \% \mathrm{SDS}$, and $200 \mu \mathrm{g} / \mathrm{ml}$ of sheared salmon sperm DNA. The labeled probe was added directly to the prehybridization solution, and hybridization proceeded at $65^{\circ} \mathrm{C}$ for $16 \mathrm{hr}$. The blot was washed to a final stringency of $0.5 \times \mathrm{SSC}$ at $65^{\circ} \mathrm{C}$ for $20 \mathrm{~min}$. Autoradiography was for 3 days at $-70^{\circ} \mathrm{C}$ with intensifying screen.

\section{Preparation of micronuclear DNA for PCR}

One microgram of $O$. nova micronuclear DNA was suspended in $1 \times \mathrm{Bal} 31$ nuclease buffer $[600 \mathrm{mM} \mathrm{NaCl}, 20 \mathrm{mM}$ Tris- $\mathrm{HCl}$ (pH 7.4), $12.5 \mathrm{mM} \mathrm{MgCl}_{2}, 12.5 \mathrm{mM} \mathrm{CaCl}, 1.0 \mathrm{~mm}$ EDTA] and incubated with 4.5 units of Bal 31 nuclease (Boehringer Mannheim) for $15 \mathrm{~min}$ at $30^{\circ} \mathrm{C}$. The volume was raised to $500 \mu \mathrm{l}$ with water and extracted once with phenol-chloroform and once with chloroform, and then precipitated with ethanol using gly- cogen at a final concentration of $40 \mathrm{ng} / \mu \mathrm{l}$ as a carrier. The precipitate was resuspended in $75 \mu \mathrm{l}$ of TE buffer $(10 \mathrm{~mm}$ Tris-HCl at $\mathrm{pH} 7.4,1 \mathrm{~mm}$ EDTA). This resuspension was the $\mu^{\mathrm{T}}$ PCR template. One microgram of control micronuclear DNA was treated identically except no nuclease was added to the reaction mix. This resuspension was the $\mu$ PCR template.

\section{$P C R$}

All PCRs for Figure 5 used 1.0 unit of Modified (exo-) Vent polymerase (New England Biolabs) with the manufacturer's Primer Extension Buffer $10 \mathrm{~mm} \mathrm{KCl}, 10 \mathrm{~mm}\left(\mathrm{NH}_{4}\right)_{2} \mathrm{SO}_{4}, 20 \mathrm{~mm}$ Tris- $\mathrm{HCl}(\mathrm{pH} 8.8), 2 \mathrm{mM} \mathrm{MgSO}_{4}, 0.1 \%$ Triton X-100) in a final volume of $50 \mu \mathrm{l}$. BSA was added to $0.1 \mu \mathrm{g} / \mu \mathrm{l} . \mathrm{MgSO}_{4}$ was added to a final concentration of $6 \mathrm{~mm}$ in the $1 \times$ reaction buffer. Each deoxynucleotide was at a concentration of $100 \mu \mathrm{M}$. PCRs with primer pairs 1 and 4 were denatured for $1 \mathrm{~min}$ at $95^{\circ} \mathrm{C}$, annealed for $1 \mathrm{~min}$ at $68^{\circ} \mathrm{C}$, and extended for $2 \mathrm{~min}$ and $30 \mathrm{sec}$ at $72^{\circ} \mathrm{C}$. PCRs with primer pairs 2 and 3 were denatured for 1 min at $92^{\circ} \mathrm{C}$, annealed for $1 \mathrm{~min}$ at $71^{\circ} \mathrm{C}$, and extended for $2 \mathrm{~min}$ at $75^{\circ} \mathrm{C}$. All PCRs were for 35 cycles. Template DNAs were as follows: $M$ reactions $=100 \mathrm{ng}$ of native macronuclear DNA; $\mathrm{K}$ reactions $=100 \mathrm{ng}$ of mic $\alpha \mathrm{K}$ clone DNA; $\mu$ reactions $=5-10$ $\mu \mathrm{l}(\sim 100 \mathrm{ng})$ of the control micronuclear DNA suspension (see Preparation of micronuclear DNA for PCR, above); $\mu^{\mathrm{T}}$ reactions $=5-10 \mu \mathrm{l}(\sim 100 \mathrm{ng})$ of the Bal 31-treated micronuclear DNA suspension.

PCRs for sequencing of macronuclear DNA were essentially as described above, except $20 \mathrm{ng}$ of native macronuclear DNA was used as template and the reaction volume was raised to 100 $\mu \mathrm{l}$ and run for 30 cycles. PCRs were denatured at $92^{\circ} \mathrm{C}$ for $1 \mathrm{~min}$, annealed at $71^{\circ} \mathrm{C}$ for $1 \mathrm{~min}$, and extended at $75^{\circ} \mathrm{C}$ for $2 \mathrm{~min}$. Six identical reactions for each primer pair (both version specific and nonversion specific) were run. Reaction products were pooled and gel-purified using a 1\% agarose gel. After extraction and precipitation, the PCR products were resuspended in $30 \mu \mathrm{l}$ TE buffer. Six microliters of each resuspension was used in the sequencing reactions. The version-specific PCRs used the primers VSF1, 5'-GAGTCTCCAAGAAGAAGACTGCCT-3' and VSH3, 5' -GTCAGGAGCTCAGCAGAGTCCTCA-3'. Nonversion-specific PCRs used the primers P0190, 5' -CAAACATGTCCACtGCCGCTAAGC-3' and M0870, 5'-TTGTTGAGgGCGGTGTACATGTCGC-3'. Underlined nucleotides indicate mismatches between the primers and the $S$ and $A$ versions. The lowercase $t$ in P0190 indicates a mismatch between the primer and the $\mathrm{S}$ and $\mathrm{K}$ versions. The lowercase $\mathrm{g}$ in M0870 indicates a mismatch between the primer and the $\mathrm{K}$ version. Conditions to obtain version-specific PCR were determined empirically by attempting to amplify cloned version A DNA (pMAC-56A; Gray et al. 1991) alongside cloned version K DNA (mic $\alpha \mathrm{K}$ ). Annealing temperatures were increased until the pMAC-56A template failed to produce PCR product visible by ethidium bromide staining on an agarose gel. This annealing temperature was found to be $71^{\circ} \mathrm{C}$. The same annealing temperature $\left(71^{\circ} \mathrm{C}\right)$ continued to produce PCR product with the mic $\alpha \mathrm{K}$ template. PCRs for sequencing of micronuclear DNA were done essentially as described above, except $5 \mu \mathrm{l}$ of Bal 31-treated micronuclear DNA resuspension was used as template in the primary PCR. A 1 : 1000 dilution of the primary PCR reaction was then used as template in a second, large-scale (six $50-\mu$ l reactions) PCR. All reactions were then pooled, and the products were gel purified on a $0.7 \%$ agarose gel. The purified PCR product was then resuspended in $50 \mu \mathrm{l}$ of water. Six microliters of this resuspension was used in each sequencing reaction. Primers used in the amplification from native micronuclear DNA were P0680 and M1300. These primers anneal in MDS 5 and MDS 13, 
respectively. The sequencing primer used (PIES6) is complementary to sequence within IES6, so that extension is from within IES6 into MDS2 and the intron region as located in the micronuclear gene. PCRs were run in a Hybaid thermal reactor (National Labnet Co.).

\section{Acknowledgments}

We thank John T. Gray for kindly providing primers, the macronuclear $\alpha$-TBP gene clone, and helpful communication of data prior to publication. We thank M. Douglas Wray for technical assistance with Figure 6. We also thank William D. Downs, Adam R. Jenkins, and Janice D. Pata, as well as many members of the laboratory, for critical reading of the manuscript. We also thank the anonymous reviewers for their helptul and thoughtful consideration of the manuscript. We thank Gayle Prescott for preparation of the manuscript. This work is supported by National Institute of General Medical Sciences (NIGMS) grant 2 ROI GM19199 to D.M.P.

The publication costs of this article were defrayed in part by payment of page charges. This article must therefore be hereby marked "advertisement" in accordance with 18 USC section 1734 solely to indicate this fact.

\section{References}

Ammermann, D. 1965. Cytologische and genetische Untersuchungen an dem Ciliaten Stylonychia mytilus. Ehrenberg. Arch. Protistenk. Bd 108: 109-152.

Baird, S.E., G.M. Fino, S.L. Tausta, and L.A. Klobutcher. 1989. Micronuclear genome organization in Euplotes crassus: A transposon-like element is removed during macronuclear development. Mol. Cell. Biol. 9: 3793-3807.

Bierbaum, P., T. Donhoff, and A. Klein. 1991. Macronuclear and micronuclear configurations of a gene encoding the protein synthesis elongation factor EF la in Stylonychia lemnae. Mol. Microbiol. 5: 1567-1575.

Boswell, R.E., L.A. Klobutcher, and D.M. Prescott. 1982. Inverted terminal repeats are added to genes during macronuclear development in Oxytricha nova. Proc. Natl. Acad. Sci. 79: 3255-3259.

Gray, J.T., D.W. Celander, C.M. Price, and T.R. Cech. 1991. Cloning and expression of genes for the Oxytricha telomerebinding protein: Specific subunit interactions in the telomeric complex. Cell 67: 807-814.

Greslin, A.F., D.M. Prescott, Y. Oka, S.H. Loukin, and I.C. Chappell. 1989. Reordering of nine exons is necessary to form a functional actin gene in Oxytricha nova. Proc. Natl. Acad. Sci. 86: 6264-6268.

Herrick, G., S.W. Cartinhour, K.R. Williams, and K.P. Kotter. 1987. Multiple sequence versions of the Oxytricha fallax 81-MAC alternate processing family. I. Protozool. 34: 429434.

Hunter, D.J., K. Wiliams, S. Cartinhour, and G. Herrick. 1989. Precise excision of telomere-bearing transposons during $O_{X}$ ytricha fallax macronuclear development. Genes \& Dev. 3: 2101-2112.

Iwashima, M., A. Green, M.M. Davis, and Y.-H. Chien. 1988. Variable region (VS) gene segment most frequently utilized in adult thymocytes is $3^{\prime}$ of the constant $|\mathrm{C} \delta|$ region. Proc. Nat1. Acad. Sci. 85: 8161-8165.

Jahn, C.L., M.F. Krikau, and S. Shyman. 1989. Developmentally coordinated en masse excision of a highly repetitive element in E. crassus. Cell 59: 1009-1018.

Klobutcher, L.A. and C.L. Jahn. 1991. Developmentally con- trolled genomic rearrangements in ciliated protozoa. Curr. Opin. Genet. Dev. 1: 397-403.

Klobutcher, L.A., C.L. Jahn, and D.M. Prescott. 1984. Internal sequences are eliminated from genes during macronuclear development in the ciliated protozoan Oxytricha nova. Cell 36: 1045-1055.

Krikau, M.F. and C. L. Jahn. 1991. Tec2, a second transposonlike element demonstrating developmentally programmed excision in Euplotes crassus. Mol. Cell. Biol. 11: 4751-4759.

Lauth, M.R., B.B. Spear, J. Heumann, and D.M. Prescott. 1976. DNA of ciliated protozoa: DNA sequence diminution during macronuclear development of Oxytricha. Cell 7: 67-74.

Prescott, D.M. and A.F. Greslin. 1992. The scrambled actin I gene in the micronucleus of Oxytricha nova. Dev. Genet. (in press!.

Prescott, D.M., C.J. Bostock, K.G. Murti, M.R. Lauth, and E. Gamow. 1971. DNA of ciliated protozoa. I. Electron microscopic and sedimentation analysis of macronuclear and micronuclear DNA of Stylonichia mytilus. Chromosoma 34: 355-366.

Ribas-Aparicio, R.M., I.J. Sparkowski, A.E. Proulx, J.D. Mitchell, and L.A. Klobutcher. 1987. Nucleic acid splicing events occur frequently during macronuclear development in the protozoan Oxytricha nova and involve the elimination of unique DNA. Genes \& Dev. 1: 323-336.

Roth, M. and D.M. Prescott. 1985. DNA intermediates and telomere addition during genome reorganization in Euplotes crassus. Cell 41: 411-417.

Straus, N.A. and R.J. Zagursky. 1991. In vitro production of large single stranded templates for DNA sequencing. BioTechniques 10: 376-384.

Tausta, S.L. and L.A. Klobutcher. 1989. Detection of circular forms of eliminated DNA during macronuclear development in E. crassus. Cell 59: 1019-1026.

Tausta, S.L., L.R. Turner, L.K. Buckley, and L.A. Klobutcher. 1991. High fidelity developmental excision of Tecl transposons and internal eliminated sequences in Euplotes crassus. Nucleic Acids. Res. 19: 3229-3236.

Yao, M.-C., C.-H. Yao, and B. Monks. 1990. The controlling sequence for site-specific chromosome breakage in Tetrahymena. Cell 63: 763-772. 


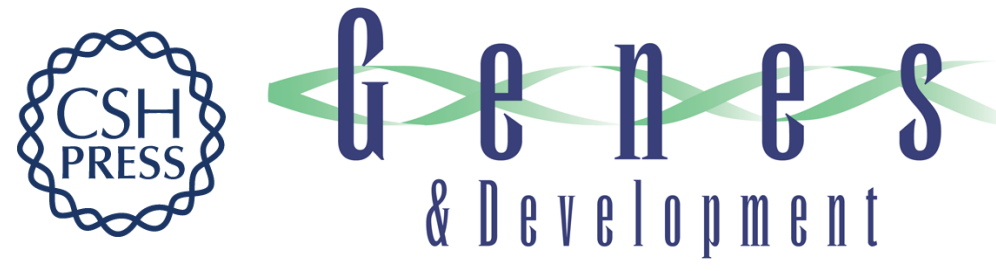

\section{Analysis of a scrambled gene: the gene encoding alpha-telomere-binding protein in Oxytricha nova.}

J L Mitcham, A J Lynn and D M Prescott

Genes Dev. 1992, 6:

Access the most recent version at doi:10.1101/gad.6.5.788

References This article cites 21 articles, 7 of which can be accessed free at: http://genesdev.cshlp.org/content/6/5/788.full.html\#ref-list-1

License

Email Alerting

Service

Receive free email alerts when new articles cite this article - sign up in the box at the top right corner of the article or click here.

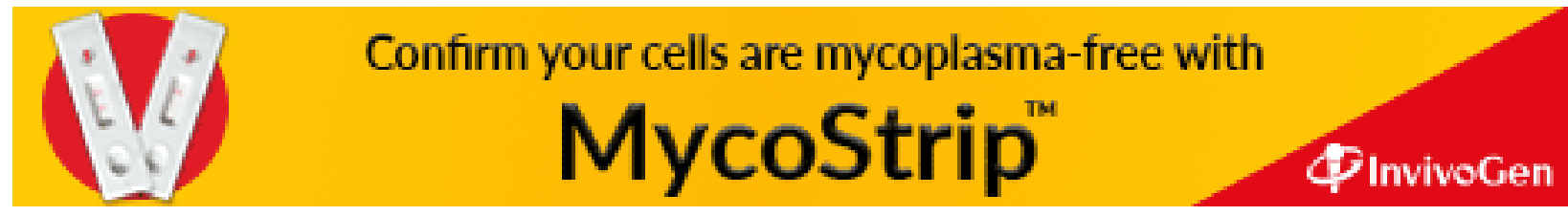

